\title{
ANALÝZA FORIEM INTERNETOVEJ REKLAMY - E-MAILOVÁ REKLAMA
}

\author{
Radovan Madleňák*
}

\section{Úvod}

Je e-mail pre internetovú reklamu dôležitý? Čo urobí väčšina užívatel'ov krátko po pripojení na Internet? Obvykle si stiahnu novú poštu! Elektronická pošta patrí medzi najobl'úbenejšie služby Internetu a môže byt' využitá ako vel'mi účinný druh internetovej reklamy. Podl'a štatistík elektronickú poštu využíva až 98\% užívatel'ov Internetu.

\section{E-mail ako reklamné médium}

Podstatou elektronickej pošty je prenos požadovanej informácie od odosielatel'a $\mathrm{k}$ adresátovi. E-mail vykazuje prvky reklamného (pasívneho) komunikačného média, ked' zadávatel' neočakáva aktívny prístup zákazníka, spätnú väzbu, a taktiež prvky aktívneho komunikačného média, vychádzajúceho z princípov priameho marketingu. Pomocou e-mailu môže zákazník nielen získat' informácie, ale môže taktiež realizovat' nákup tovaru [3].

Zasielanie informácií od odosielatel'a $\mathrm{k}$ adresátovi prostredníctvom elektronickej pošty, vo forme jednoducho zobrazitel'ných, vytlačitel'ných a prenosných elektronických listov alebo dokumentov, sa ponúka pre využitie v marketingu ako nositel'a marketingových informácií. E-mailová reklama je dnes vel'mi rýchlo rastúcou oblast'ou. Špecifickými znakmi reklamného e-mailu sú rýchlost', finančná nenáročnost', interaktivita, meratel'nost' odozvy a možnost' presného cielenia na zákazníka. Podstatným prínosom je úspora času a skvalitnenie starostlivosti o zákazníka.

Dôvod, prečo je však v súčasnosti e-mailová reklama málo využívaná, vyplýva zo skutočnosti, že množstvo zadávatel'ov reklamy považuje reklamu realizovanú prostredníctvom elektronickej pošty za SPAM. O elektronickej pošte sa v súvislosti so slovom SPAM (rozosielanie nevyžiadanej reklamnej pošty) neustále píše v technických časopisoch, kde sa popisujú jeho nevýhody a negatívne reakcie užívatel'ov Internetu. Rozosielanie nevyžiadanej reklamnej pošty na vel'ké množstvo e-mailových adries získaných z „pochybných“ databáz je nebezpečná marketingová taktika a nie je odporúčaná ani internetovými odborníkmi. Spamming je však vel'mi lacný, môže zasiahnut' vel'ké množstvo adresátov, ale je neetický a o jeho účinnosti sa dá taktiež diskutovat' [2].

Podl'a prieskumov, ktoré boli vyhotovené na českom Internete (pokusné rozosielanie nevyžiadanej reklamnej pošty) sa účinok takejto reklamy pohybuje okolo pol promile $(0,05 \%)$. Pritom je táto forma reklamy sprevádzaná vel'kým počtom e-mailov od rozčúlených užívatel'ov (tzv. flames), ktorí nevyžiadanú poštu prijali.

\footnotetext{
* Ing. Radovan Madleňák, PhD., Žilinská univerzita v Žiline, Fakulta Prevádzky a ekonomiky dopravy a spojov, Katedra spojov, Univerzitná 1, 01026 Žilina, tel. č.: 041/513 3124, fax: 041/ 5655 615, e-mail: Radovan.Madlenak@fpedas.utc.sk
} 


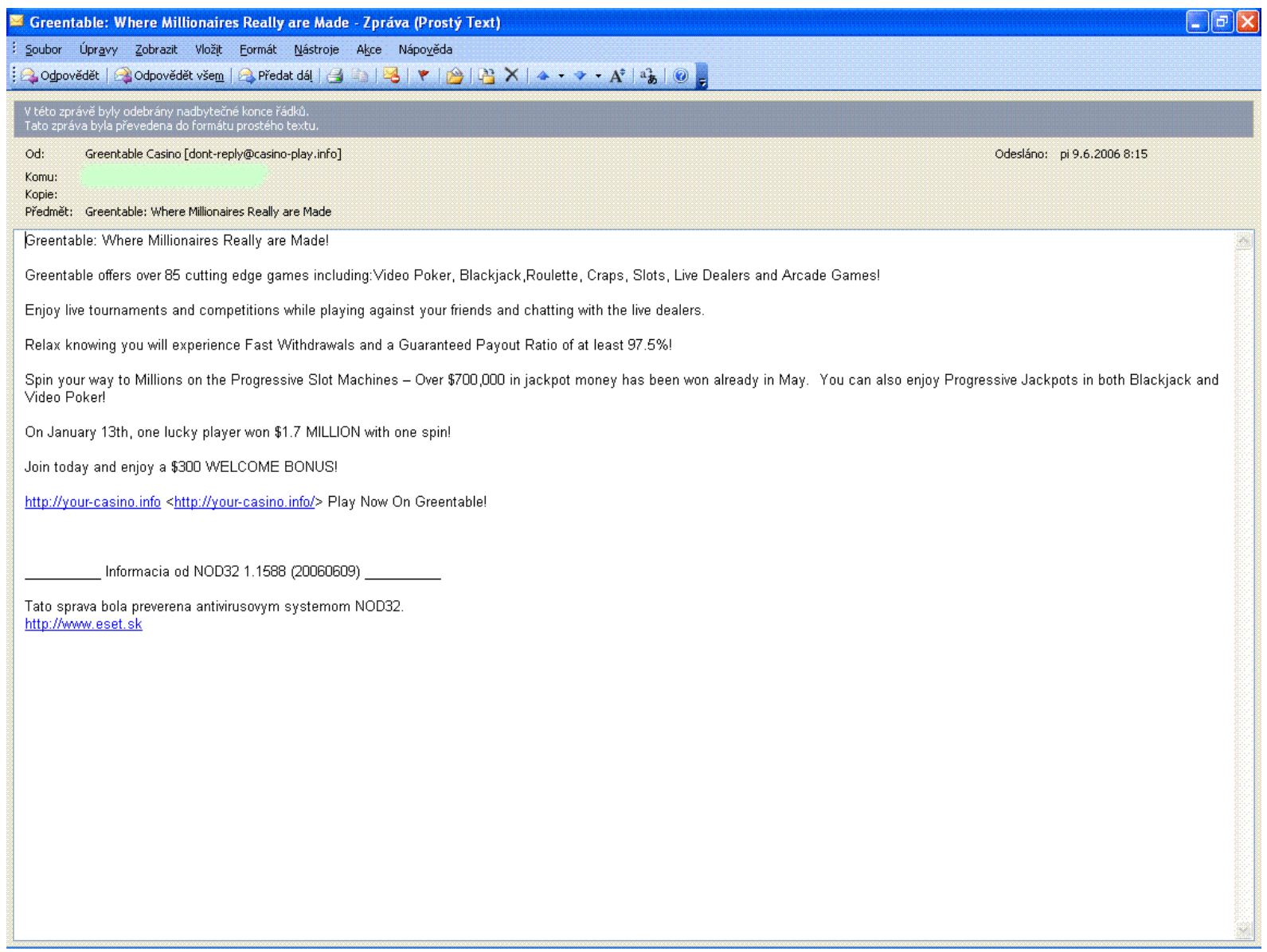

Obr. č. 1 Nevyžiadaný reklamný e-mail - SPAM

Rastúce množstvo SPAM-u však jednoznačne dokazuje rast jeho obl'úbenosti, aj ked' v poslednej dobe má skôr klesajúcu tendenciu. V Európskej únii je posielanie nevyžiadaných správ zakázané od 31. 10. 2003. Podl'a Európskej komisie toto zahlcovanie predstavuje vážnu prekážku v rozvoji elektronického obchodovania a budovania informačnej spoločnosti.

Bill Gates začiatkom roka 2004 vyhlásil, že o dva roky bude SPAM minulost’ou. Podl'a všetkého sa Gatesove predpovede nielenže nenaplnili, ale reálny stav sa ešte zhoršil. V roku 2002 sa podiel SPAM-u na celkovej e-mailovej komunikácii odhadoval na 17\%, v súčasnosti sa odhaduje, že až 85\% všetkej e-mailovej komunikácie je SPAM alebo škodlivé emaily obsahujúce vírusy.

Existujú však aj bezpečné a nenásilné metódy ako využit' elektronickú poštu pre potreby internetovej reklamy. Hlavným dôvodom ich využitia je predovšetkým niekol'konásobne vyššia účinnost', ako je to v prípade Webu.

\section{Formy e-mailovej reklamy:}

Medzi základné druhy e-mailovej reklamy patrí:

- Reklamné vsuvky vložené do bežného e-mailu;

- Sponzorstvo diskusných skupín;

- APM (Authorized Permission Mail), autorizovaný reklamný mail (ARM) [4].

\section{Reklamná vsuvka vložená do bežného e-mailu}

Ide o ,jemnejší" druh e-mailovej reklamy, ktorý je adekvátne tomu menej účinný. Ide o akúsi vsuvku do klasického e-mailu, ktorý dostáva užívatel' kvôli jeho obsahu, a reklamu 
prijíma ako súčast' tohto e-mailu. reklamné vsuvky by mali byt' krátke, mali by byt' vysádzané holým textom, odsadené od ostatného textu a najlepšie označené slovom „Reklama".

Využitie e-mailov s reklamnými vsuvkami:

- pri tzv. newsletter, teda pravidelných e-mailových spravodajcov, ktoré si vyžiada užívatel' kvôli ich obsahu,

- v prípade používania tzv. free-mailových služieb, všetky e-maily prechádzajú centrálnym serverom, ktorý ich spracováva (prijíma a odosiela), a obvykle sa na ich koniec „,prilepí" krátka reklamná vsuvka,

- V prípade najrôznejších potvrdzovacích e-mailov (napr. potvrdenie o prihlásení, nákupe tovaru, atd’.) ktoré sú generované programom a nie človekom.

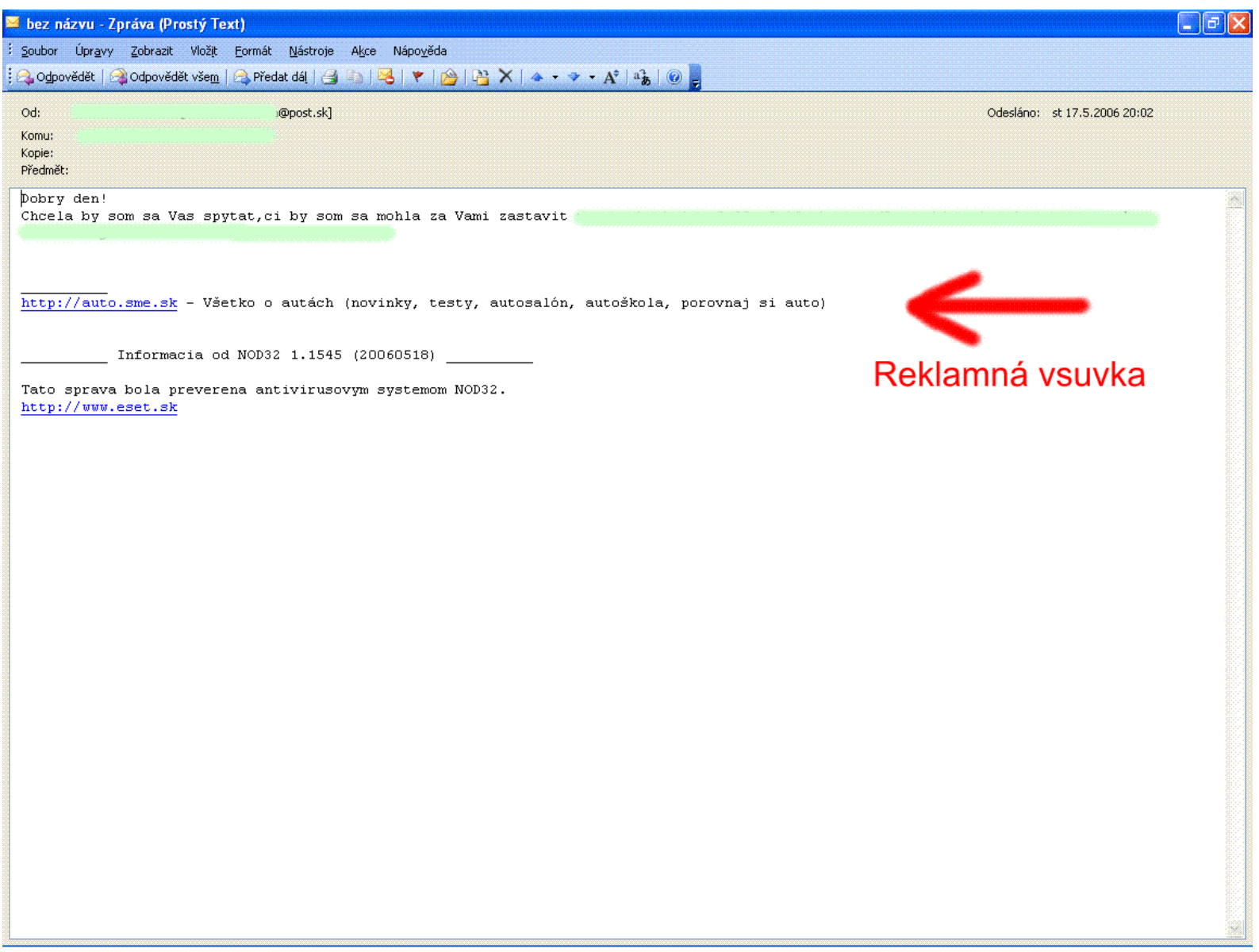

Obr. č. 2 Reklamná vsuvka umiestnená na záver e-mailu

Umiestnenie reklamných vsuviek:

- na konci e-mailu. Táto forma umiestňovania reklamných vsuviek je najčastejšia pri free-mailových službách. Je považovaná za adekvátnu kompenzáciu od poskytovatel'a free-mailových služieb voči svojím zákazníkom, ktorí jeho službu využívajú zadarmo. Sú samozrejme najmenej účinné, jednak nie každý čitatel' dočíta e-mail až do konca a vsuvku si vôbec nepovšimne, alebo pokial' čitatel' dočíta celý e-mail, už nepokračuje d’alej;

- na začiatku e-mailu. Umiestnenie vsuvky na začiatok e-mailu predstavuje „tvrdší" útok na užívatel'ovo súkromie a tieto druhy vsuviek sa nikdy nepoužívajú 
vo free-mailoch, sú však časté v newsletteroch. Newsletter je vlastne internetový časopis, ktorý dostáva užívatel' zadarmo a jeho prijímanie si dobrovol'ne zvolil;

- uprostred e-mailu alebo v kombinácii na viacerých miestach. Tato možnost' je opät’ typická pre newsletter, pretože ten býva väčšinou dlhý a rozsiahly.

\section{Sponzorstvo diskusných skupín}

Diskusných skupín je na Internete nespočetné množstvo. Obvykle sa jedná o diskusie niekol'ko desiatok, stoviek až tisícov l'udí, ktorí si prostredníctvom diskusných skupín (news) vymieňajú svoje názory na aktuálnu problematiku. Okrem klasických skupín realizovaných službou NEWS, pre čítanie ktorých musí mat' užívatel' nainštalovaný špeciálny softvér (ten je obvykle súčastou e-mailového klienta), existuje aj mnoho skupín realizovaných formou klasickej elektronickej pošty. Nové správy, reakcie a postrehy, ktoré sa objavia v diskusnej skupine, sú všetkým účastníkom automaticky ihned' rozosielané ich poštových schránok. Takto rozosielané e-maily sú výborným prostriedkom pre prenos reklamného odkazu. Pokial' nie je diskusia v skupine dost' "rýchla" a účastník diskusie dostáva do svojej schránky len niekol'ko správ, existuje pravdepodobnost', že si užívatel' takýto e-mail prečíta. Prvých niekol'ko riadkov e-mailu je ideálnym miestom pre umiestnenie krátkej reklamnej pasáže. Prevádzkovatelia diskusných skupín umiestňujú reklamné oblasti do záhlavia a inzerentov v ňom obvykle označujú ako sponzorov, pretože podporujú existenciu diskusnej skupiny.

Sponzorstvo diskusných skupín má niekol'ko výhod. Z marketingového hl'adiska sa $\mathrm{v}$ diskusnej skupine stretávajú l'udia s jedným spoločným záujmom - zúčastnit' sa diskusie na danú tému. Pre inzerentov vytvárajú diskusné skupiny marketingové segmenty. Dá sa teda predpokladat', že reklamné odkazy upozorňujúce napr. na nový typ mobilného telefónu budú uverejnené v diskusnej skupine venujúcej sa mobilnej komunikácii a tam vyvolá väčší záujem užívatel'ov, ako pri použití klasického reklamného banneru umiestneného na Webe.

Avšak aj diskusné skupiny, realizované prostredníctvom elektronickej pošty, majú svoje nevýhody. Účastníci skupiny sú síce záujmovo zjednotení, ale vd’aka globálnemu prístupu k Internetu nie je možné presne určit', z ktorého regiónu pochádzajú.

Vel'kou nevýhodou diskusných skupín je ich „nadmerná aktivita“. Pokial' sa diskusie v skupine aktívne (teda nie len čítaním, ale aj reakciou na novú správu) účastní vel'ké percento účastníkov, narastá objem denne doručovanej pošty do schránok účastníkov diskusnej skupiny a pravdepodobnost', že účastník si správu prečíta sa znižuje. A to až do okamihu, kým je množstvo každodenne prijímanej pošty neúnosné a účastník prestáva správy čítat', alebo sa z danej skupiny jednoducho odhlási [5].

\section{Autorizovaný reklamný mail (ARM)}

Ďalšou možnost’ou prenosu reklamného odkazu je vyžiadaná reklamná pošta. Užívatelia, ktorí dostávajú tento druh pošty, určitým spôsobom súhlasili s tým, že im firma môže na nimi uvedenú e-mailovú adresu zasielat' reklamnú poštu. Stránky firemných prezentácií preto často obsahujú vstupné polia pre základné e-mailové adresy, kde užívatel' zadá svoju adresu, ak si želá byt' pravidelne informovaný o aktuálnej ponuke firmy, prípadne o výhodných ponukách, ktoré pre svojich klientov firma pripravila.

E-mailové adresy užívatel'ov sa prostredníctvom WWW stránok snažia získat' nie len komerčné subjekty (za účelom ponuky produktov), ale aj rôzne časopisy (webziny) vychádzajúce na Internete [1]. Pokial' užívatel' zadá do špeciálneho formuláru e-mailovú adresu, začne mu daný časopis pravidelne zasielat' prehl'ad článkov v aktuálnom "čísle“ (vydaní) spolu s odkazmi na dané články. Užívatel' tak nemusí denne prechádzat' všetky svoje obl'úbené internetové časopisy a vyhl'adávat' nové správy, ale nechá si zaslat' prehl'ad, ktorému sa hovorí internetový bulletin (newsletter). 


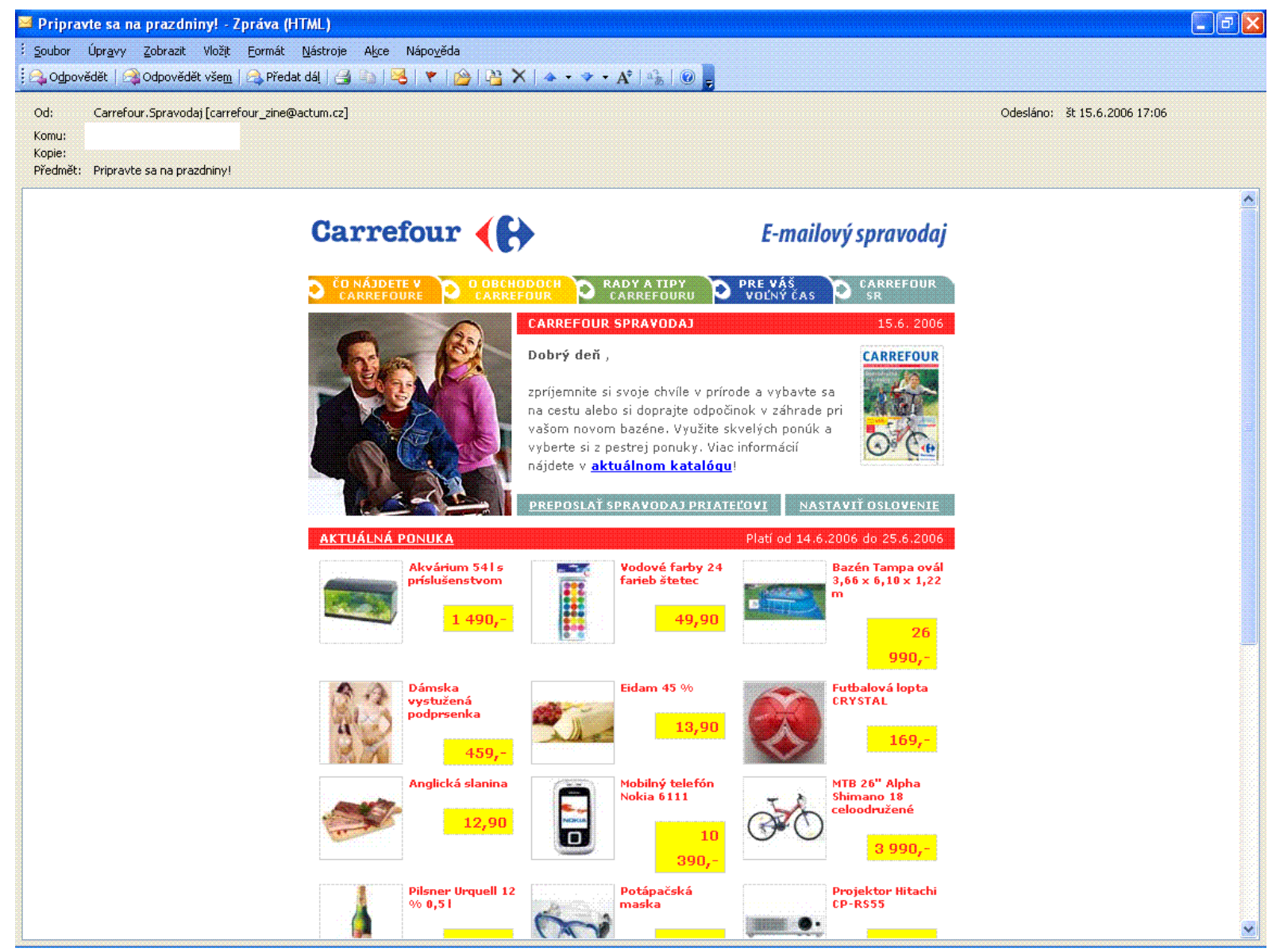

Obr. č. 3 Newsletter v HTML formáte - Ponuka produktov

Oba typy reklamnej pošty - konkrétne ponuky produktov, či informačný bulletin - je možné získat' v klasickom textovom formáte, alebo vo formáte HTML. Prijatý e-mail potom vyzerá ako WWW stránka, čo má hned' niekol'ko výhod. Na rozdiel od klasického textového formátu umožňuje zobrazit' všetky prvky WWW stránky, takže je omnoho pestrejší a skôr upúta pozornost' čitatel'a.

Medzi článkami, alebo ponukou produktov sa môže vo formáte HTML objavit' tiež reklamná plocha. Tak ako u každého typu propagácie aj v prípade reklamnej pošty vo formáte HTML existuje vel'a nevýhod. Užívatelia nemusia mat' taký typ prehliadača pošty, ktorý by im umožnil zobrazit' poštu vo formáte HTML. Vd'aka pokročilým technológiám a rýchlemu rozvoju softvéru pre výber a rozoslanie pošty sa však percento týchto užívatel'ov neustále znižuje. Iným problémom je vel'kost' pošty. HTML formát je obvykle niekol'ko násobne väčší než klasický strohý text. Najčastejšie sa obrázky, ktoré sú súčast’ou HTML mailu, obvykle nat'ahujú až dočasne, t.j. nie sú zasielané priamo s e-mailom, ale načítajú sa z internetu až pri jeho prehliadaní. Pokial' nie je užívatel' $v$ tejto dobe pripojený na internet, obrázky sa mu nezobrazia. $Z$ toho dôvodu využíva vel'a firiem vo svojich HTML mailoch len farebný text a prvky neobsahujúce obrázky.

\section{Výhody a nevýhody e-mailovej reklamy}

Reklamná kampaň využívajúca služby e-mailu prebieha čisto v prostredí Internetu, tak ako je to pri banneroch. Rozdiely medzi nimi nie sú vel'ké, ale napriek tomu má e-mailová reklama svoje výhody:

- pokial' chce zadávatel' reklamy propagovat' rozsiahle informácie o produkte, je výhodnejšie použit' e-mail z dôvodu obmedzeného rozsahu banneru. 
- $\quad$ v prípade, že zadávatel' reklamy prezentuje produkt, ktorý je atraktívny sám o sebe a pre jeho propagáciu stačí jednoriadkový, dostatočne výstižný a provokatívny text, je zbytočné tvorit' bannerovú reklamu, ale úplne postačí vkladat' reklamné vsuvky za text do e-mailov,

- e-mailovú reklamu je výhodné použit', pokial' chce zadávatel' reklamy propagovat' viacero odkazov na rôzne webové stránky zároveň. Pri bannerovej reklame je to takmer neriešitel'né, ale pri e-mailovom inzeráte úplne bezproblémové,

- e-mailovou reklamu je možné využit' v prípade, ak bude reklama realizovaná pomocou metód virálneho marketingu, t.j. reklamy v štýle ,pošli tento e-mail desiatim d'alším l'ud'om ...",

- e-mailovou reklamu nie je vhodné použit' tam, kde zadávatel' reklamy potrebuje prezentovat' určitý dej, značku (logo) produktu [6].

\section{Záver}

Aktívny spôsob propagácie prostredníctvom e-mailu je vo svete žiadaný a využívaný, aj napriek rozmáhajúcej sa nevyžiadanej pošte. V prostredí siete Internetu sa často e-mailová reklama doplńa s bannerovou reklamou, pričom ich kombináciou je možné oslovit' rôznou formou, rozdielne ciel'ové skupiny. Využitie e-mailu pre marketingové aktivity sa zatial' nachádza $\mathrm{v}$ počiatkoch, ale jeho využitie bude do budúcna vel'mi široké.

\section{Literatúra}

[1] ČOREJOVÁ, T.: K problematike hodnotenia internetových obchodov. In: Rozvoj Euroregiónu Beskydy : skúseností - očakávania - perspektívy. - V Žiline: Žilinská univerzita, 2002. - ISBN 80-8070-015-X. - S. 22-28.

[2] HLAVENKA, J.: Internetový marketing. Computer Press, Praha, 2001. ISBN 80-7226$498-2$

[3] KREMEŇOVÁ, I., ROSTÁŠOVÁ, M.: Marketing v službách : Marketingový informačný systém, 1. vyd. - V Žiline : Žilinská univerzita, 2005. - 110 s., AH 6,95, VH 7,28 : obr., tab. - ISBN 80-8070-358-2.

[4] MADLEŇÁK, R.: Elektronický obchod, Žilinská univerzita v Žiline, Žilina, 2004, 160 str., ISBN 80-8070-192-X

[5] STUCHLÍK, P.; DVOŘÁČEK, M.: Marketing na Internetu. Grada Publishing, Praha, 2000. ISBN 80-7169-957-8

[6] VACULÍK, J.: Internet marketing - advantages and disadvantages In: "Postal Telecommunication" : Szczecin - Swinoujscie, 27-28.11.2003. - Szczecin: Fundacja na rzecz Uniwersytetu Szczecińskiego, 2003. - ISBN 83-89142-22-8. - S. 43-46.

\section{Grantová podpora}

1/1265/04 VEGA MŠ SR a SAV - Výskum siet’ových procesov v rámci odvetvových zoskupení firiem SR

1/2591/05 VEGA MŠ SR a SAV - Vplyv výberu efektívnej stratégie na udržiavanie konkurencie schopnosti podniku v rámci liberalizácie poštových trhov 